Die Lösung von Umweltproblemen hängt immer mehr davon ab, ob es gelingt, Konflikte über die Risiken und Chancen umweltrelevanter Vorhaben im Vorfeld antagonistischer Auseinandersetzungen und politischer Krisen so anzugehen, daß die beiden Kriterien der Fairness und der Kompetenz erfüllt sind. Fairness bedeutet, daß jeder betroffene Bürger im Prinzip die Möglichkeit hat, an der Entscheidung mitzuwirken. Kompetenz bedeutet, daß die möglichen Folgen von Entscheidungsoptionen nach dem besten Stand des verfügbaren Wissens abgeschätzt werden. Ein Verfahren, das diesen beiden Kriterien Rechnung trägt, besteht aus drei Schritten: einer Befragung von Interessengruppen bezüglich ihrer Werte und Kriterien zur Beurteilung der Handlungsoptionen, einer Befragung von Experten mit dem Ziel, konsensuell die Auswirkungen einer jeden Handlungsoption unter Beachtung der im ersten Schritt erfaßten Kriterien zu bestimmen, und schließlich eine Bewertung dieser Optionen durch nach dem Zufallsverfahren ausgesuchte Bürger, die mittelbar oder unmittelbar betroffen sind. Am Beispiel der Klärschlammbeseitigung in New Jersey werden die Vorzüge und Grenzen der neuartigen Verfahrensweise erörtert.

\section{Anticipating Conflicts: Public Participation in Managing the Solid Waste Crisis}

\author{
Ortwin Renn* and Thomas Webler
}

This irivolvement process is illustrated with an example about sewage sludge management.

Keywords: solid waste management, citizen participation, conflict management

\section{Prelude: The Situation}

The State Department of Environmental Protection was holding a public hearing in Lancaster, a small town in Central Massachusetts, concerning the siting of a municipal waste incinerator. The town hall was still nearly filled at 10:20 p.m., almost an hour after the scheduled closing time. For two hours residents listened peacefully while regulatory officials explained why the plant was needed, how much trash it would burn, and how much pollution it could legally emit. Expert scientists supported the officials by supplying evidence and arguments about the "acceptability" of the level of risk posed by an incinerator. The regulators thought they were being sensitive to the citizens when they kept to the agenda and, at 9:00, opened the floor for a half hour of questions. Now it was late, but the citizens were in an uproar and they showed no sign of letting up.

»What about our gardens? «, one woman asked, »Will we be able to eat the vegetables we grow? I have an organic garden and I don't want it contaminated with dioxin«. Another gentleman was interested in the contract. "Are you telling us that we have to sign a contract to supply 2000 tons of trash every year? What if we want to start a recycling program? And, after a lengthy discourse by one of the tired scientific experts to a question about respiratory illness and particulate emissions, one angry couple blurted out: »You're killing our children!« At 11:15 p.m., a respected town official suggested everyone go home for the evening. The State officials were tired, but considered their job done. They had held the legally required public hearing. All they had to do was respond to comments in written form, and continue with the permitting process. So they thought ...

\section{Introduction: Limits of Conventional Participation}

The Lancaster case is not an isolated incident in solid waste management. Almost all industrial countries face a legitimation crisis with respect to siting waste disposal facilities "I.

\section{Opposition to \\ waste disposal and handling facilities has become \\ a world-wide phenomenon \\ that puzzles experts and alienates public officials from their clients.}

Sometimes the local opposition wins, sometimes the proposer of such a facility. Rarely, however, does the process convey the impression of competent decision making and fairness vis-a-vis the affected population. But the story of Lancaster is not yet complete. The public hearing marked only the first stage in the battle between the proposer, regulators, and citizens.

During the next few weeks, some of the furious citizens organized an ad-hoc citizen initiative and vowed to stop the incinerator. They had heard the government's argument; they knew the town, like many others across the country, faced a serious problem of waste disposal; 
but incineration just didn't make sense to them. In their meetings they expressed concerns over health and environmental damage from air pollution, over the huge refuse-hauling trucks speeding down their town roads, and over the fears that their town would be perceived as a dumping ground for the region. On the other hand, they spoke admirably of recycling, and traded tips on ways to reuse plastic bags, reduce paper towel use, and compost vegetable wastes and leaves. They could not understand why the incinerator received so much support among officials and the experts, when, to the citizens, the options of recycling, reducing, and reusing waste were left unexplored, let alone implemented.

In the battle that ensued, the citizens finally won - to an extent. They were able to stop the incinerator. But the same regulatory officials who were so eager to help them solve their waste problem vis-a-vis an incinerator, were insulted and unwilling to help the town start a recycling program. The town made an attempt to initiate a voluntary recycling program, but eventually bought into an incinerator that was sited about 45 miles away. The problem was just too big for one small town to handle alone.

One is tempted to ask: Did the conventional procedure of participation work in the Lancaster case? Some would say that it did. The public was given an opportunity to become involved in the decision making and they used it to their advantage. They got what they wanted: they learned about the risks and stopped the incinerator. From a micro-perspective they won, but in a larger perspective all participants lost. An incinerator was built in another community that was less yocal about their concerns. The potential risk for the exposed public was identical; however, it was accepted by those with less resources to fight (usually poorer communities). The residents of Lancaster had opted for an integrated waste management plan, they did not succeed, but bought into an incinerator elsewhere. Finally, the public officials, who originally sought to help the community, did not only experience a defeat in what they thought was a sensible and fair solution, they also suffered an erosion of trust and confidence relating to their competence of protecting the public.

This story of Lancaster exemplifies the dilemma of policy making in the area of solid waste management. It is not a unique case. Many landfills are reaching capacity, incinerators face major public opposition, and recycling and waste reduction programs fail to be effectively implemented. The waste, however, is piling up day by day and a solution has to be found soon.

The solid waste crisis
is forcing regulatory agencies,
public interest groups, and
academic researchers
to examine just what is wrong with
conventional participation in
decision making
about environmental and health risks,
and to innovate
new approaches to
how decisions are made and
implemented.

\section{Fairness and Competence in Collective Decision Making}

What corporal attributes must a decision making process have when a decision proposal has a multiplicity of potential impacts on several affected groups? At the foundation of a society are the needs for socialization and social integration. The former refers to bringing all individuals into the fabric of the culture - to build shared meaning, a sense for community, a responsibility to act appropriately. The latter means to build a specialized division of labor that will serve to enable society to fulfill its needs for survival and reproduction. Norms for collective action can be derived from these two needs, because they are so basic to our social order.

Democratic societies fulfill the normative need of political socialization by promising every citizen an equal opportunity to take part in the collective decision making process through election and direct participation. At the center stage of socialization is the quest for social justice. Since pluralistic societies have many competing value clusters relating to the substance of social justice, conflicts among competing goals and interpretations of justice demand a fair process in which individuals and groups must have the opportunity to bring their concerns and preferences into the collective decision process. Faimess sets minimal requirements for informing and involving the public; or, if harmed by an unfair process, a person can seek legal redress. This criterion of fairness seeks to ensure that all citizens have an opportunity to become involved in their own governing, which is a central element of the socialization process.

Modern societies fulfill the normative need of social integration through an intricate web of division of labor. As the scale of human societies has grown, so has the capacity for damage, both to ecology and to ourselves. In order to anticipate more accurately the consequences of decision outcomes, modern societies have built institutions and complex procedures to develop and apply social and empirical technologies, and to measure the performance of these tools in terms of expected outcomes. The more the anticipated outcomes match the actual outcomes of the decision the more competent was the decision process. In order to be competent, that is to provide knowledge which anticipates the potential consequences of each decision option, all relevant knowledge available concerning the anticipated consequences of the decision has to be collected, digested, and processed.

\author{
Fairness and competence \\ are therefore the two yardsticks of \\ how to evaluate the quality of \\ decision processes \\ in modern democratic societies.
}

Many of the decisions that are currently being made in the area of technological and environmental risk management challenge the capacities of the traditional decision making models for being fair and competent. At a theoretical level, Jürgen Habermas has worked at the problem of how understanding is built by examining social actions in terms of speech acts. His conception for the "ideal speech situation", which presumes symmetry and reciprocity conditions, can be viewed as a rational discourse in which both fairness and competence are accomplished $\mid 2,3\}$. Unfortunately Habermas is not very specific about how such an ideal discourse can be structured and implemented. To deal with this challenge, many new approaches are being developed and some have been applied ${ }^{[4-9]}$.

We have had experience developing and testing one such model that shows promise, and have tested it in the context of decision making about the management of municipal sewage sludge. This model, which we have labeled the "three-stage model of participation", 
is based on the combination of three participation tools: value-tree analysis, Group Delphi, and citizen panels. Valuetree analysis was first developed by Detlof von Winterfeldt and Ward Edwards ${ }^{110}$. The Group Delphi is a modification of the classic Delphi process (11, 12). The citizen panels are modeled after the concept of planning cells ("Planungszelle") originally developed by Peter Dienel at the University of Wuppertal ${ }^{[13]}$. These three tools are described in more detail in the next section.

\section{The Three-Step Participation Model}

\section{Prerequisites of the Model}

At the center of the three-step participation model are two working hypotheses:

(1) that the goal of fairness can be met by giving experts, interest groups, and affected citizens access to the decision process and by using the method of random selection for assuring equal opportunity for any given citizen to become involved in the process;

(2) that the goal of competence can be met by integrating the specific knowledge that experts, stakeholders, and affected citizens can offer to identify and anticipate potential impacts of decision options.

What are the three steps in our decision model?

\section{Step 1: Identification and Selection of} Concerns and Evaluative Criteria

The first step in policy or decision making is often the identification of objectives or goals that the decision process should serve once a problem is identified or a political program established. Identification of concerns and objectives is best accomplished by asking all relevant stakeholder groups (socially organized groups that are or perceive themselves as being affected by the decision) to reveal their values and criteria for judging different options. It is important that all relevant stakeholder groups are represented and that a variety of value clusters, including economic, political, social, cultural, and religious values, is integrated into the analysis. Although strategic reasoning and hidden agendas may influence the responses of stakeholder groups, the mere

Table 1. The Six Steps of Eliciting Value-Trees.

\begin{tabular}{|c|c|}
\hline Step No: & Description of the Step \\
\hline 1 & $\begin{array}{l}\text { Personal interview(s) between the analyst(s) and several representatives of the } \\
\text { respective stakeholder group. }\end{array}$ \\
\hline 2 & $\begin{array}{l}\text { Structuring the values, criteria, and attributes into a hierarchical order by the } \\
\text { analyst(s). }\end{array}$ \\
\hline 3 & $\begin{array}{l}\text { Feedback of the value-tree to the stakeholder group for comments or } \\
\text { modification. }\end{array}$ \\
\hline 4 & Iteration of process until stakeholder group is satisfied with the final product. \\
\hline 5 & Combination of all group specific value-trees into a single "megatree". \\
\hline 6 & $\begin{array}{l}\text { Validation of the megatree by all participating groups (with the option of } \\
\text { assigning zero weights to criteria that they dislike). }\end{array}$ \\
\hline
\end{tabular}

listing of concerns as expressed in values and, subsequently, the deduction of criteria helps to expose inconsistencies and to avoid hidden agendas.

To elicit such values and criteria the technique of value-tree analysis has proven appropriate ${ }^{[10.14]}$. A value-tree identifies and organizes the values of an individual or group with respect to possible decision options and structures the elicited values, criteria, and corresponding attributes in a hierarchy, with general values and concerns at the top, and specific criteria and attributes at the bottom ${ }^{114,151}$. Table 1 shows the six consecutive steps of eliciting value-trees.
Value-trees have proven to be useful instruments in structuring the underlying dimensions of a debate and in linking the general concerns of groups with the concrete options that they favor or disfavor ${ }^{[15]}$.

Value-trees

help to focus attention on issues that seem

to underlie conflicts about

the selection of options

and to develop a mediation program between conflicting groups.

Table 2. Sequence of a Group Delphi.

\begin{tabular}{ll}
\hline Step & Description \\
\hline $\begin{array}{l}\text { 1. Development of } \\
\text { Questionnaire }\end{array}$ & $\begin{array}{l}\text { Based on the criteria and options, a numerical scale should be } \\
\text { developed that is best suited to elicit expert judgments on the } \\
\text { performance of each option on each criterion. }\end{array}$
\end{tabular}

2. Selection of Experts

3. First Plenary Session

4. First Group Session

5. Second Plenary Session

6. Second Group Session

7. Iteration of Plenary Session and Group Work

8. Evaluation of Results

9. Validation
Selection of experts with different points of view about the subject and representing relevant, but diverse disciplines.

Introduction into the Group Delphi process and the issue in question. The procedure of how the options and the criteria were derived is explained to the participants.

All participants are randomly divided into groups of 3-4 people. Each group is asked to complete the questionnaire. Group consensus is the goal, but minority votes are allowed.

The results of the group assessments are handed out to all participants. The groups whose ratings deviated the most from the median values of all groups are asked to defend their point of view in front of all participants. The defenses are openly discussed (and taped for evaluation).

The participants are divided in small groups again, this time according to the principle of systematic rotation. The groups are asked to complete the same questionnaire, taking into account what they learned in the plenary discussion.

Steps 5 and 6 are repeated until no further changes occur in the responses of groups or the positions of the participants are established and all arguments have been exchanged.

The ranges of the numerical results of the last round are taken as the best expert estimates for the impact analysis. The (video)tapes provide arguments and evidence for the final scale values or explain the distribution of expert opinions.

The results and the justifications are sent to all participants for final comments or second thoughts on the subject. In addition, the results can be peer-reviewed by other experts who did not participate in the process. 


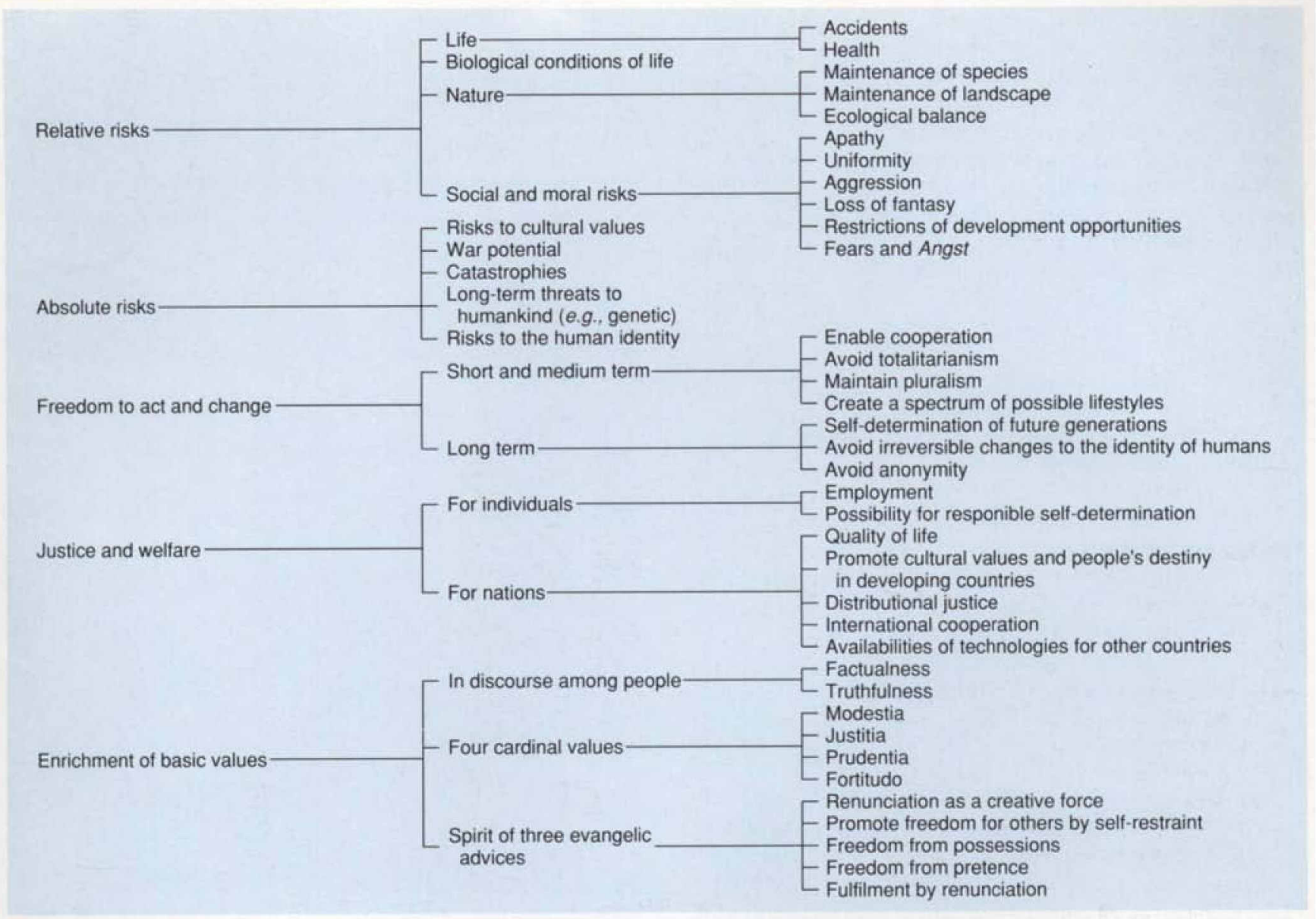

Figur 1. Example of a Value-Tree: Values of the German Catholic Church to Evaluate Energy Systems.

The resulting output of such a valuetree process is a list of hierarchically structured values that represent the concerns of all affected parties. Figure 1 illustrates an example of a value-tree. The tree in Figure 1 represents the values of the German catholic church with respect to energy systems. Interesting to note here is that the representatives of the church made a clear distinction between absolute risks (threats to human survival), which were intolerable regardless of low probabilities, and relative risks, which can be traded off against benefits.

\section{Step 2: Identification and Measurement of Impacts and Consequences Related to the Different Options}

The evaluative criteria derived from the value-tree are operationalized and transformed into indicators by the research team or an external expert group. These operational definitions and indicators are reviewed by the participating stakeholder groups. Once approved by all parties, they serve as measurement rules for evaluating the performance of each option on different value dimensions. This provides a common rationale for producing consistency in the measurement and evaluation of potential options. The elicitation of options is also part of this step (preferably after the criteria have been defined). In principle, options can be found by brainstorming within the research team, by interviews with stakeholder groups, or by political precedent. With different policy options and criteria available, experts representing varying academic disciplines and viewpoints about the issue in question are asked to judge the performance of each option on each indicator.

For this purpose, we have developed a special method called the Group Delphi ${ }^{111.121 .}$

\section{The major objective of a Group Delphi is to divide a group of experts into small working groups, to compare the judgments of these groups in a plenary session, and to identify the areas of uncertainty and dissent among the experts.}

The more one of the group's ratings deviate from the median of all other groups the more time is allocated to this group to defend and substantiate its judgment. This justification procedure assures that relevant information is shared among the participants so that differences in evaluations are not based on ignorance but on different interpretations of the existing data. There is direct testing for dissent in a "peer review" process. In addition, the Group Delphi produces not only numerical values and distributions, but also verbal explanations for deviations from the median. Each round contributes to the clarification of the issues and leads either to a consensus or the formation of dissenting camps with diverging views and corresponding argumentation. The sequence of a Group Delphi is shown in Table 2.

The Group Delphi is similar to the original Delphi format, but based on group interactions instead of written responses. The objective is to reconcile conflicts about factual evidence and reach an expert consensus via direct confrontation among a heterogeneous, 
preferably representative, sample of experts in the field. The desired outcome is a performance profile for each option. This profile specifies the range of scientifically legitimate and defensible expert judgments for each indicator, illustrates the distribution of these opinions among the expert community, and includes verbal justifications for opinions that deviate from the median viewpoint.

\section{Step 3: Aggregation and Weighting of the Impact Profiles by \\ Randomly Selected Citizens and \\ Elicitation of Citizens' Preferences}

The last step in our process is the evaluation of each option profile by one group or several groups of randomly selected citizens ${ }^{\mid 13 !}$.

The objective is to provide citizens with the opportunity to learn about the technical and political facets of the policy options and to enable them to discuss and evaluate these options and their likely consequences using their own sets of values and preferences.

The participants are informed about the potential options and the corresponding consequences before they are asked to evaluate these options on each dimension identified in the value-tree process. If deemed necessary by the participants, the list of concerns can be augmented or restructured. Since the process requires time for the educational program and the evaluation of options, the panels are conducted in seminar form over three to five consecutive days All participants are exposed to a standardized program of information.

The idea is to conduct a process similar to a jury trial with experts and stakeholders as witnesses, facilitators as "professional" judges, and citizens as jurors who make the final determination.

Citizen panels are organized into three major components: (1) reception of information through lectures, field tours, videos, written material, and others; (2) processing of information through small group discussions, plenary sessions, and hearings; and (3) evaluation of impacts of options through small group discus-
Table 3. Typical Sequence of a Citizen Panel.

Steps Activity in Citizen Panels

1 Introduction to issue through lecture and field tour.

2 Background knowledge through lectures, written material, self-educating group sessions, audio-visual information, field tours, and others.

3 Introduction of conflicting interpretations of information through videos or hearings.

4 Introduction of options through lectures (non-controversial) or hearings (controversial).

5 Problem-structuring with respect to each option through group sessions and plenary discussions.

6 Introduction of value-tree and - if desired - addition of values to the existing tree.

7 Evaluation of options elicited through individual questionnaires and group discussions (captured in group response forms).

8 Drafting of rough recommendations through work-groups and plenary sessions.

9 Articulation of recommendations in a citizens' report by the facilitator after the completion of the citizen panels.

10 Feedback of citizens' report to participants (usually in an evening meeting two months after the citizen panels).

11 Presentation of the citizens' report to the initiator, the media, and interested groups.

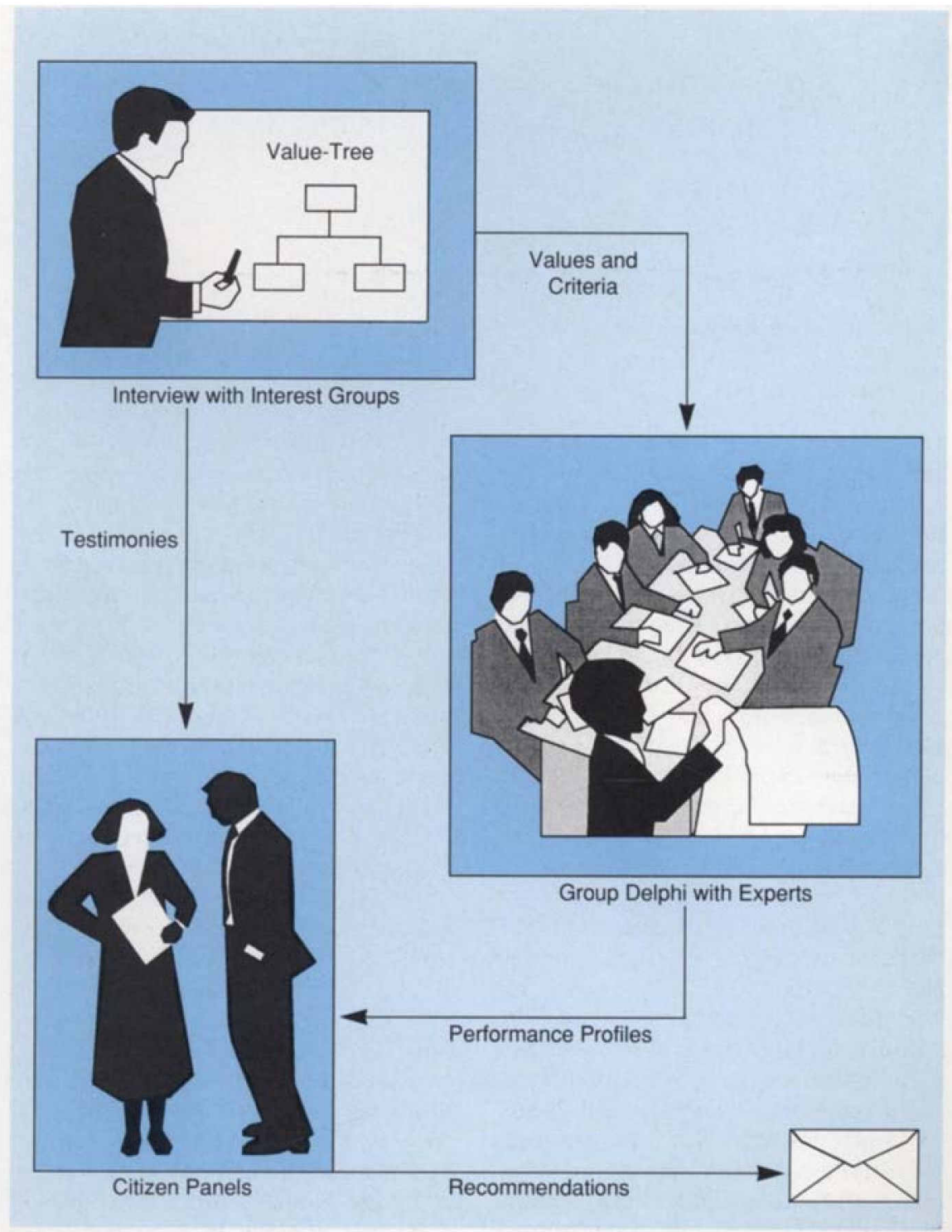

Figure 2. Schematic Description of the Three-Step Participation Model. 


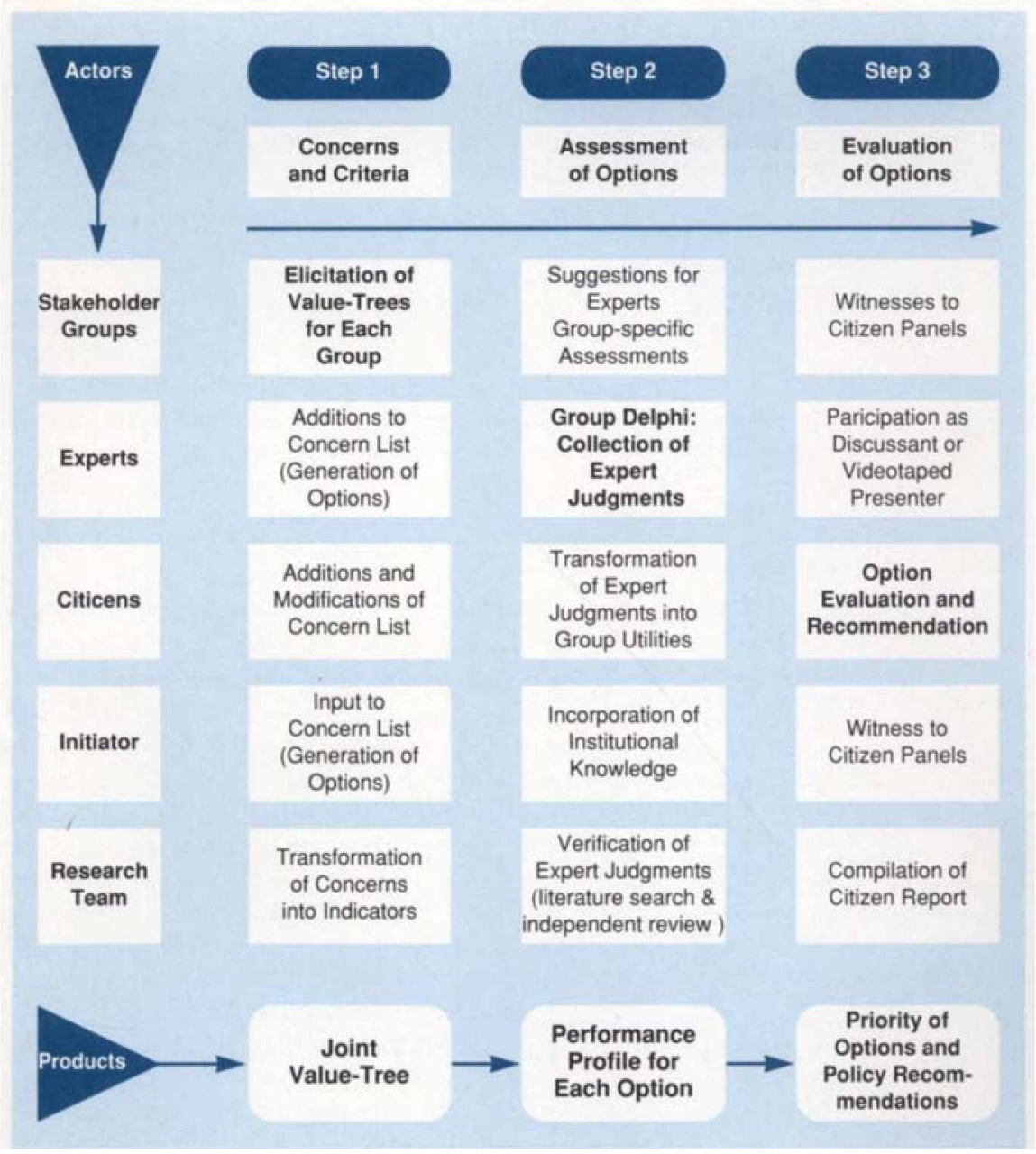

Figure 3. Basic Concept and Elements of the Three-Step Model.

sions, personal judgments, and consensus-building exercises in the plenary. Informing the participants about the planning options and their likely consequences is the most vital part of the whole procedure. The major requirement is that all expert camps be equally represented in the information package and that they be allowed to present their own case ${ }^{116.171}$. The impacts identified by the experts and the ratings of each option are the raw material for the written or videotaped information that the participants of the citizen panels receive. The use of the results of the Group Delphi in citizen panels serves two functions. First, it provides a reliable and appropriate source of factual information; second, it demonstrates the neutral position of the facilitator. Table 3 lists a typical sequence of a citizen panel.

The practice of enlisting citizen panels for policy evaluation and recommendation has been applied to many policy problems in the Federal Republic of Germany ${ }^{[13,18-20)}$, but to our knowledge has never been implemented in

the United States of America except for our pilot project in New Jersey ${ }^{[17]}$. Similar panels with randomly selected citizens have been organized by the "Institute for New Democratic Processes" in Minneapolis ${ }^{[4,21]}$ and by a group of local transportation planners in Boulder, Colorado ${ }^{|22|}$. In addition, the traditional jury system in the United States has adopted the principal idea of using common sense and public values as input for the judicial decision making process ${ }^{[23]}$.

The model of citizen panel differs from the more popular mediation approaches in conflict resolution: Mediation is a procedure of negotiating an agreement among the key actors involved in a desision. It relies on the existence of organized groups and their willingness to submit themselves to a procedure of balancing their interests. The leaders of these groups convene and, assisted by a facilitator or moderator, work on an acceptable compromise. Citizen panels, however, represent the common populace, not distinct interest groups. They don't negotiate solutions based on their personal interests but act as value consultants for making better public decisions. However, both procedures are inspired by the same principles of pursuing a fair and competent solution to a current conflict.

\section{Overview of the Three-Step Process}

The functions and procedure of this policy model are illustrated in Figures 2 and 3 . The figures show that all actors involved (the experts, the stakeholder groups, the citizens, the initiator, and the research team) play a role in each step - to meet the criteria for fairness, but their influence is channelled to the type of knowledge and rationality that they can offer best - to meet the criteria for

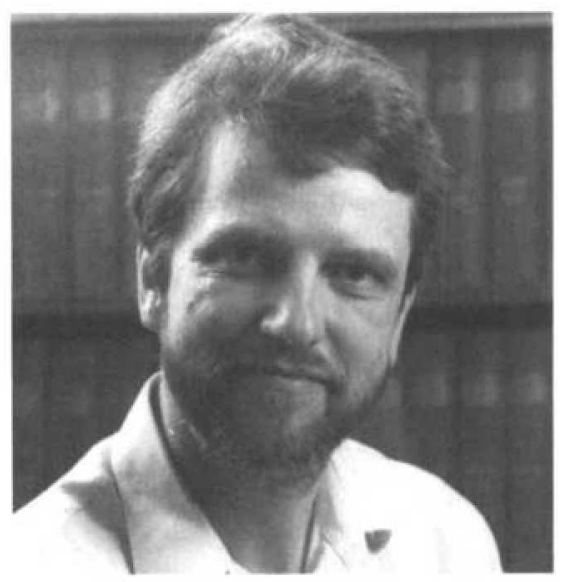

Ortwin Renn: Born 1951 in Schmidtheim, Nordrhein-Westfalen, Germany. He is Associate Professor for Environment, Technology, and Society at Clark University in Worcester (Massachusetts) and has an appointment as senior investigator at the Clark Center for Technology, Environment, and Development (CENTED), an interdisciplinary research institute devoted to the study of hazards and risks in contemporary societies. Renn directed this center from 1989 to 1990 . From 1990 to 1991 he chaired Clark's Peace Study Program and the Center for Global Education. Prior to joining Clark, he directed a research unit for technology assessment at the largest governmental research center in the Federal Republic of Germany (National Research Center KFA, Jülich). Renn received a MA degree in Sociology and Economics (European Diploma) and a doctorate degree in Social Psychology, both from the University of Cologne (School of Economics and Social Sciences). His main research interests are risk analysis and perception, risk communication, public participation, environmental psychology, and social movements. Renn has published five books and more than 50 articles in journals or chapters in books. He serves on several national and international advisory boards and has been a member of the panel on environmental standards of the West-German Academy of Sciences and Technology in Berlin from 1988 to 1991 . 
competency (these are highlighted in bold face in Figure 3). The stakeholders are the principal source for building value-trees, but the other parties may augment the joint tree. Experts are principally responsible for constructing performance profiles for each option, taking into consideration the institutional knowledge of the sponsor and the specific knowledge of the various stakeholder groups. The major task of the citizens is to evaluate options and generate or modify policies assisted by expert and stakeholder witnesses. The role of the initiator is limited to making suggestions about options and to providing testimony to the citizen panels. Finally, the research team has the primary task of providing first drafts of the three products (joint value-tree, performance profiles, and citizen report), to gain approval for these products from the respective actors, and to feed them back into the process. This division of labor introduces checks and balances into the process and constitutes a structural order that is logical and transparent.

Had the three-step participation process been applied in the Lancaster case (confer Sections 1 and 2) of the regional solid waste problem and the proposed incinerator, it would have given the citizens an opportunity to have their preferences factored into the decision. For example, the final decision for waste management might have combined incineration with a mandatory recycling program and limited landfilling.

\section{An Illustration of the Three-Step Process}

\section{Sludge as a Solid Waste Management Problem}

In the United States of America, the State of New Jersey is facing a severe crisis in solid waste management. Until recently, much of its policy consisted of dumping solid waste at sea. Over $40 \%$ of New Jersey's sewage sludge was being disposed of in this way ${ }^{124 \mid}$. However, in 1988 , the Federal government ordered that ocean dumping of sludge had to cease. State regulatory officials had anticipated this, and were hopeful that they could manage the sludge by recycling it as fertilizer, rather than landfilling or incinerating it.

Appropriateness of land application of municipal sewage sludge as an option for sludge management is controversial. The major advantage is that the sludge is

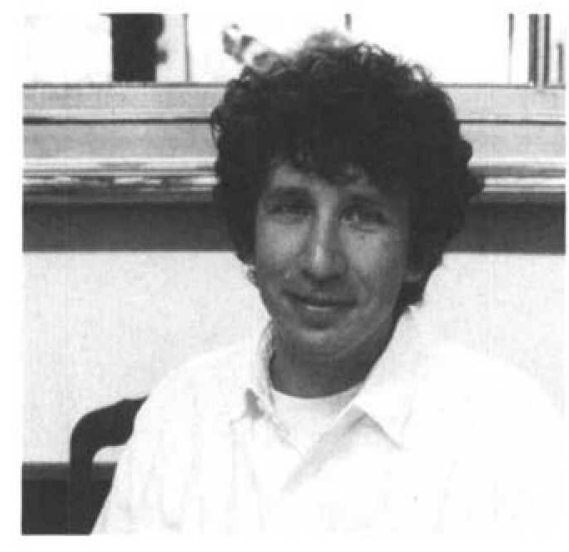

Thomas Webler: Born 1960 in Philadelphia, Pennsylvania, USA. He is a Ph. D. graduate student at the Department for Environment, Technology, and Society of Clark University and holds a bachelor degree in science and a master degree in bioengineering. He has been involved in several research projects focusing on citizen involvement and integration of knowledge for designing and evaluating environmental policies. His main research areas are public participation, critical social theory, and environmental sociology. He has published seven articles in scientific journals and is co-developer of a patent. He also works as a consultant in the areas of environmental policies and energy planning and is currently the editor of the Newsletter "Energy, Policy, and Environment". In addition to his academic interests, Webler has served on the conservation commission of Harvard, Massachusetts, and has been involved in serveral environmental groups.

recycled as a fertilizer for crops, reducing the amount of chemical fertilizer needed. The associated risks pertain to the health threats that compounds routinely found in the sludge pose to humans ${ }^{[23]}$. These compounds are added to the soil when the sludge is applied. Behavior of these compounds differs once in the soil. They may be taken up by plants; removed by volatilization, runoff, or wind; leach down into the soil or groundwater; adsorb to soil particles; or be destroyed by photo- or biodegradation processes.

Due to the wide variety of hazardous contaminants, the number of human exposure pathways is relatively high, and include, among others: consumption of contaminated crops, groundwater contamination, disease vectors, and direct ingestion of soil. Besides the risks posed by the incorporation of sludge to soils, additional risks are associated with the transport and storage of sludge. Health and environmental risks are accompanied by the impacts of odor, aesthetic changes, and social and economic costs. The New Jersey Department of Environmental Protection has responded to these concerns with regulatory provisions which include limitations on concentrations of sludge contaminants and performance requirements for sludge transport, storage, and application.

\section{Application of and Modifications to the Three-Step Process}

In 1989, the New Jersey Department of Environmental Protection (NJDEP) awarded a grant to our research team to experiment with citizen participation for determining public preferences about local sludge management in Hunterdon County. We elicited the concerns, reactions, and recommendations of citizens to a proposed research project in which municipal sewage sludge was to be applied to the fields of an experimental research farm recently acquired by Rutgers University. Although the research farm proposed to apply only a small amount of sludge, much larger land application programs had been carried out in other parts of the state, and people in this mainly agricultural county were aware that a statewide sludge management plan using land application could have major impacts on their livelihood. This project was a litmus to sample the publics' responses to a land application strategy.

This was the first time that our citizen panel model had been applied in the United States of America, therefore we reviewed the project context to determine what changes, if any, were prudent. During interviews with the affected constituency of citizens, stakeholders, and politicians, we discovered that the value dispute was not prevalent. Instead of constructing a value-tree for Step I, we used the information from our interviews for input to the procedure. The Group Delphi was conducted as described in Section 4. Some changes were made with respect to the citizen panels. Although reimbursing participants for lost work pay has been a chief aspect of the original German model, we dropped this characteristic since voluntarism is such a strong tradition in America and payment could be easily mistaken for bribery, particularly by people not selected to participate. To compensate for this change, we scheduled meetings on two consecutive weekends.

The envisioned program for the citizens panel was radically altered after the participants, in particular the land owners abutting the site, made it clear that they were not willing to specify the conditions under which the project of land application would be acceptable to 
them. Rather than working on regulatory provisions or modifications that would make them change their mind, the panels decided to review the regulations and to explain their arguments and concerns.

\section{Citizens want to determine the agenda of their participation. If a public agency defines the options too narrowly, the citizens will add thier own choices or reject the limited choices that were given to them.}

The proposed sludge management project at the Rutgers Experimental Farm was finally rejected by the citizen panel. As a result of this recommendation, Rutgers University withdrew its proposal.

\section{Results of the Group Delphi}

We conducted the Group Delphi a month before the citizen panels were scheduled. Nine experts from several universities, federal and state regulatory bodies, and a consulting firm participated in the one-day event. Group Delphi participants had a twofold task: (1) to assess the health risks from application of municipal sewage sludge to farmland; and (2) to assess the capability of the state regulations at mitigating those risks. As Figure 4 shows, the experts assigned low risk and high confidence to risks from heavy metals. These have been extensively studied and are considered to be well understood. But they assigned high risk and low confidence to some organic toxins such as furans and dioxins, PCB's, and polyaromatic hydrocarbons (PAH's). These substances are relatively new, they exist in vast numbers of types, and they have been little studied. While the Group Delphi participants showed some uncertainty about the health effects of the substances that could contaminate food crops or ground water, they felt that, with only one exception, the New Jersey regulations were more than adequate to protect the public from the possible risks. The exception was lead. Lead is a well studied heavy metal that poses a significant risk to human health. The experts agreed that the New Jersey regulations were too lenient on lead, and they recommended tightening up the regulation.

Figure 4. Results of Expert Workshop on the Risks of Toxins in Municipal Sewage Sludge.

Table 4. Concerns Raised by Expert Workshop. I

\begin{tabular}{|c|c|c|c|c|c|}
\hline Group 1 & & Group 2 & & Group 3 & \\
\hline Concern & Priority & Concern & Priority & Concern & Priority \\
\hline Odors & 1 & $\begin{array}{l}\text { Insurance and Cost for } \\
\text { Clean-up }\end{array}$ & 1 & $\begin{array}{l}\text { Odor (How will the } \\
\text { odor be controlled so } \\
\text { that it does not impact } \\
\text { my quality of life) }\end{array}$ & 1 \\
\hline $\begin{array}{l}\text { Pathogens } \\
\text { (health, concerns, move- } \\
\text { ment to groundwater) }\end{array}$ & 2 & $\begin{array}{l}\text { Ground/Surface Water } \\
\text { Contamination }\end{array}$ & 2 & $\begin{array}{l}\text { Regulation } \\
\text { (Who is going to } \\
\text { ensure project } \\
\text { control?) }\end{array}$ & 2 \\
\hline
\end{tabular}

Heavy Metals

(crop effects, soils,

3 Air Contamination

migration to water)

Toxic Organics

(crop, wildlife, soils, water)

\section{Groundwater Control} nutrients, pathogens)

\section{Monitoring}

(who does it, how frequently, for what record keeping, availability of records)

Surface Water Control (effect on wells, metals nutrients, pathogens)

Traffic

(increase in traffic, road damage, drag out)

Wildlife Concerns

(hunting, consumption of game)

\section{Land Values}

(property values, future use) (effect on wells, metals

4 Food-chain Contamination

5 Soil Contamination and Mobility

6 Environmental

Persistence

of Pollutants

$7 \quad$ Recordkeeping and Monitoring

\section{Effect on Future Land Use 8 Vectors}

(Rodents, flys, pets will transport contamination into my home)

9 Public Access to Site

9

(Resale or development potential of my property in the future)

10 Real Estate

10 Food Processor

(If I use sludge grown crops, will the public accept my product?)

Odor

1) Question: If you were an abutter to the Snyder Farm, what would be your major concern?

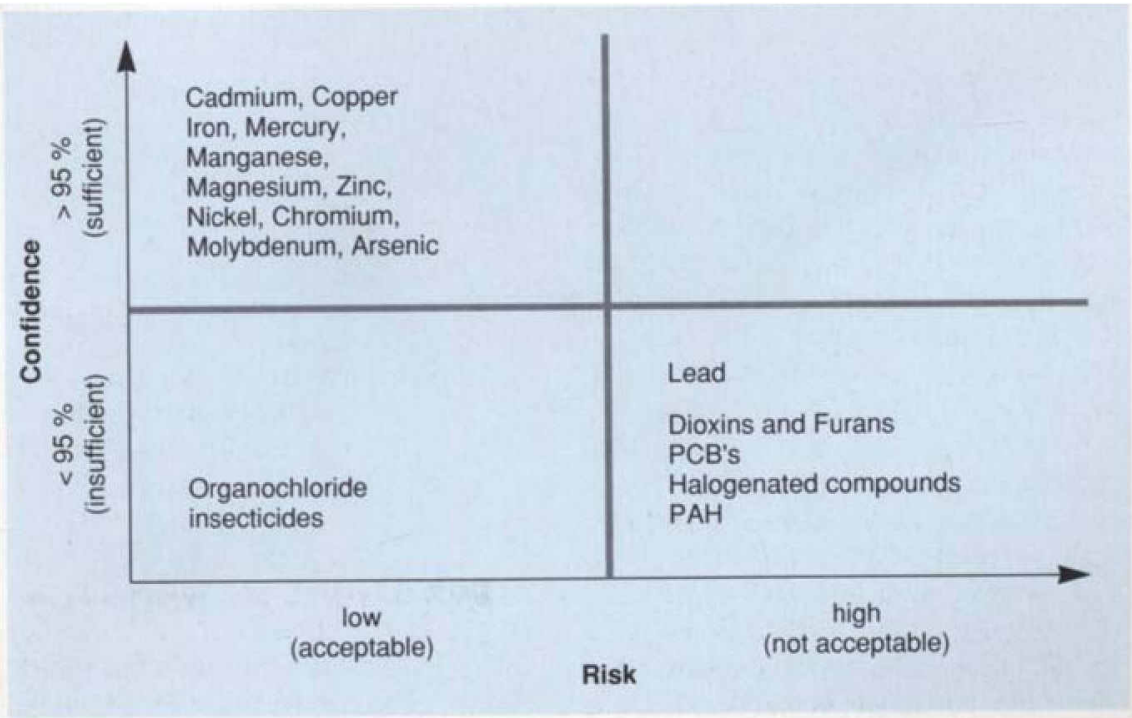




\section{Concerns of Citizens and Experts}

Experts: To investigate the experts' concerns, we divided the nine participants into three groups of three and asked them to imagine that they lived near the proposed site and they had been asked by their neighbors to participate on the community's behalf. They were to compose a list of ten concerns that they would raise as being the most important, and prioritize this list. These lists are presented in Table 4.

Group 1 chose "odor" as their primary concern, but classified their second, third, and fourth choices in terms of contaminants. Direct possible consequences of these contaminants (contamination) were addressed in the fifth, seventh, and ninth places. Group 2 saw "insurance and cost of clean-up" as the primary concern, but the following five concerns were expressed as forms of contamination. Group 3 agreed with the first group that "odor" was the most important. Their following priorities were a mix of practical issues (for example, "who will guarantee the regulation?"), forms of contamination, contaminants, and social fall-out ("town becomes sludge dump for county"). All three groups mentioned secondary consequences of hazard events, but with the exception of the second group's primary concern, these items received low rankings. All of these concerns can be associated with the negative connotations of there being a waste disposal site located in the town.

Causal agents (contaminants) and their undesirable distribution (contamination) occupied the foremost priorities for the experts. This seems consistent with the experts' scientific perspective (understanding causal relations), but does not necessarily correspond with the citizens' concerns. Practical concerns not necessarily risk-related ("who will regulate?", "who will keep the records?") ranked second, sixth, seventh, and eighth on the experts' lists.

Citizens: Participants of the citizen panels were asked to list their major concerns with respect to the proposed land application research project. After listening to presentations about land application and specific information on the Rutgers research proposal, the participants were asked to prioritize the list of concerns. Both tasks, the elicitation of concerns and the prioritizing were done in three small groups of about 5-6 members. Table 5 presents the citizens concerns and priorities as given by the three groups.
Group 1 rated social and economic about property devaluation, the possibility that the respected image of Rutgers University might be tarnished, and general distrust of the New Jersey Department of Environmental Protection (NJDEP) among town residents. Group 2 placed high priority on concerns for regulating the sludge application project. They especially felt that groundwater contamination must be avoided. They were also concerned about their town becoming a "sludge dump" for the county. Group 3 focused only on contamination and preventing its occurrence. They also had a minor concern for the transportation of sludge through the town.

Of the remaining thirteen unranked concerns, nine centered around mitigative aspects: making the sludge cleaner, restricting application limits, and monitoring for contamination. Concerns for odor, health, or environmental effects of contaminants were few. The single most articulated health-related concern was groundwater contamination. Most participants associated either insufficient enforcement of existing regulations or the continuation of leach-out after the sludge application has ceased with cerned that, once the sludge had been concerns the highest. They were worried these concerns. The citizens were con-

applied, problems would persist over a period longer than the New Jersey Department of Environmental Protection would be capable of handling.

To better understand the citizens' concerns for the risks from heavy metals in the sludge, we devoted one morning to a discussion of the risks and potential health effects from land application of sludge containing these compounds. Concerns were elicited and ranked in the plenary discussion. The top two concerns were long-term effects on the land and long-term maintenance of the residual contamination, long after sludge application had ceased. Clearly, the participants focused on long-term impacts. The transformation of farmland into "wasteland" was of utmost concern. One participant expressed this view in stating: "What are 40 or 50 years to a farmer if the farmland is in the family for generations? I would like to hand this land over to the next generation without compromising its ability to grow crops. The land is all $\mathrm{I}$ can pass on.«

Comparison of Expert and Citizen Concerns: Concerns of the citizens who participated in the citizen panels and the experts who participated in the Group Delphi were almost inversely related.

Table 5. Concerns and Priorities of Participants of the Citizen Panels.

\begin{tabular}{|c|c|c|c|c|}
\hline \multirow[t]{2}{*}{. } & \multirow[t]{2}{*}{ List of Concerns } & \multicolumn{3}{|c|}{ Priority } \\
\hline & & Group 1 & Group 2 & Group 3 \\
\hline 1 & $\begin{array}{l}\text { Pre-treatment of sludge (strict parameters and } \\
\text { industry specific) }\end{array}$ & & & \\
\hline 2 & $\begin{array}{l}\text { Education of local residents (avoid emotional } \\
\text { responses) }\end{array}$ & & & \\
\hline 3 & Basic distrust of DEP and other authorities & 3 & & \\
\hline 4 & Monitoring wells on site & & & \\
\hline 5 & Prevention of groundwater contamination & & 3 & \\
\hline 6 & Soil testing & & & \\
\hline \multirow[t]{2}{*}{7} & Future monitoring of soil and groundwater after & & & \\
\hline & application ceases & & & 1 \\
\hline 8 & Transportation of sludge material & & & 5 \\
\hline 9 & $\begin{array}{l}\text { Honesty towards the citizens (not just positive } \\
\text { information, loss of credibility) }\end{array}$ & & & \\
\hline 10 & Removal of industrial chemicals from sludge & & & \\
\hline 11 & Removal of household chemicals & & & \\
\hline 12 & Uptake of chemicals in the food chain & & & \\
\hline 13 & Effective regulation (independent testing) & & & \\
\hline 14 & Odor & & & \\
\hline 15 & Decline of property values & 1 & & \\
\hline 16 & Health effects from pathogens & & & \\
\hline 17 & Limitation of applied quantity & & & \\
\hline 18 & Limitation of time period for application & & 1 & \\
\hline 19 & Image of Rutgers & 2 & & \\
\hline 20 & Frequency of testing & & 2 & \\
\hline \multirow[t]{2}{*}{21} & "Foot in the Door" problem (gradually extending & & & \\
\hline & the sludge application program) & & 4 & \\
\hline 22 & Responsibility and liability for clean-up & & & 2 \\
\hline 23 & Runoff water & & & 3 \\
\hline 24 & Containment of the experimental area & & & \\
\hline 25 & Timing between testing and application & & & 4 \\
\hline
\end{tabular}


The citizens' major area of concern was the least important to the experts. Contrastably,

the experts' major area of concern was among the least for the citizens.

The panel participants were concerned about mitigative effects: sludge quality standards, application and site specific standards, and monitoring to avoid future contamination. In comparison, the experts expressed no concern for sludge quality or application and site specific standards, and placed only moderate emphasis on monitoring. Contrary to the experts, the citizens did not express direct concern about potential health impacts or environmental damage. Experts placed almost half of their concern on pollutants (outcomes) and contamination (exposure). Citizens preferred to focus on preventing the outcomes or exposure, including ensuring that the sludge meets minimum performance requirements before it is applied.

Second, the citizens expressed strong concern for secondary consequences of possible hazard events. We classified these as being primarily of social or economic nature. Experts were somewhat more concerned for secondary consequences than they were for mitigative effects, but the total concern was still quite small and focused on aspects such as odor, noise, and inconvenience. The participants of the citizen panels were much more concerned about the longterm social impacts that the land application would have, such as the transformation of a rural area into a semiindustrial region and the negative sideeffects of social change in the community, and unwelcome economic transitions.

\section{Results of the Participation Process}

The elicitation of concerns was only one part of the citizen panel exercise. The citizens were also asked to review the New Jersey regulations and to make suggestions for regulations that they would recommend for the proposed sludge application. As indicated above, the citizens refused to make these suggestions since they rejected the proposed sludge application project and felt it would be counterproductive to submit suggestions for making the proposal more feasible. Instead, they articulated their discomfort with a decision process in which they had no input in designing or reviewing different options. The citi- zens had the suspicion that their decision would open the door for a largescale disposal program that would transform the character of their community. They were particularly aggravated that the State had decided to site a large landfill in the community two months prior to the panel meetings. Many participants expressed their outrage over this decision and felt that they had taken their share of the burden and it would now be up to other communities to be targeted for sludge disposal.

The outcome of the panels was partly disappointing but not unexpected. In spite of a common overall goal (waste management and risk reduction) and an honest approach to meet the citizens' needs, concerns of experts, regulators, and the affected public were not identi$\mathrm{cal}$, but revealed major conceptual differences in how they viewed the problem and perceived potential solutions. The regulators were not able to address the concerns of the citizens, in particular their worry over the long-term effects of sludge application and the transformation of their community, and to dispel their concerns. Since no other alternative was offered, a rejection of the proposal was likely.

However, under difficult conditions, the process did successfully foster a degree of interactive understanding between government officials, stakeholders, citizens, and technical experts. This is uncharacteristic of most siting efforts. Citizens did receive the educational component and interview scientific experts and public officials; they did discuss and express their personal concerns, values, and preferences; and some decision options were evaluated. Although they were not pleased with the choice of options available, the citizens did indicate a desire to participate in the policy formation process and generated a thoughtful document that outlined their concerns and reasons for rejection.

This experiment led the New Jersey Department of Environmental Protection to review its sludge disposal policies and to find better regulatory tools to address the specific concerns of the public. In addition, they began an integrated waste management plan that incorporates waste reduction and early separation of sludge in order to minimize risks and to make the long-term impacts of application less severe. It is too early to evaluate these new policies, but they seem to move in the right direction. Furthermore, citizen involvement is a mandatory part of the sludge disposal program.

\section{Conclusions: Society's Need for a Fair and Competent Participation Process}

The philosophy behind citizen panels is that citizens, experts, and stakeholders can resolve environmental conflicts through their respective expertise. Stakeholders are valuable sources for concerns and criteria to evaluate options, since their interests are at stake. Experts are needed to provide technical data and point out relations between options and impacts. Citizens must live with the consequences, and are therefore the best judges to evaluate the decision options. Citizen panels are intended to bring these three perspectives together in a productive fashion.

Any public participation must meet the criteria of fairness and competence. The experience with the three-step participation model shows that the structure of the process is capable of providing an arena for meeting these two requirements: the process integrates the relevant knowledge to anticipate potential consequences and makes this knowledge available to all participants.

\section{Involving randomly selected citizens assures that all potentially affected persons have an equal opportunity to incorporate their values and preferences in the decision.}

We believe the public is capable of comprehending complex issues and making decisions beyond those which maximize their own personal gain. Most people take the responsibility of community involvement extremely seriously. Successful public involvement depends on a procedure which supports discourse and full consideration of evidence, rationales, and options. With such a tool, citizens will articulate wellconsidered policy recommendations. A procedure that allows citizens to demonstrate their potential, and includes technical and political knowledge needed for holistic analysis, would enhance society's ability to manage risks. The proof of this assertion will lie in further experimentation with innovative procedures.

One of the key conclusions of this experiment was that the participation model must match the social and political context of the issue in question. Based on our experiences in Germany 
and New Jersey, it appears that some conditions for the success of citizen panels are demanded:

- variability of options: the issue must have several feasible options, each with advantages and disadvantages;

- equity of exposure: there should be a roughly equal exposure to the disadvantages of these options among the local population;

- participation of randomly selected citizens: even controversial issues can be dealt with if attitudes are not already polarized and if the majority of participants are randomly selected ${ }^{[18.20]}$;

- personal experience: citizens should have enough experience with the issue that they feel confident about learning and discussing decision options;

- openness of initiator: the initiator must be willing to seriously consider the recommendations of the panel.

The case study in New Jersey violated several of these conditions and therefore it did not come as a surprise that the citizens rejected the proposal. The New Jersey case documented clearly that understanding each participant's perspective is a necessary but not a sufficient condition for reaching a compromise. If value conflicts are impossible to resolve, or if concerns of participants cannot be adequately addressed, a compromise may be difficult to reach. In these instances, a discourse has to be established that may continue over longer time periods ${ }^{[9]}$. There is no guarantee that such a process works, but in the long run there is no alternative.

One might be tempted to ask: If citizen involvement is so difficult and painful, why should governmental agencies bother to promote participation or go beyond the mandated public hearing to elicit citizens' concerns? In addition to legal requirements, the first response to this question is that social acceptance of any policy is closely linked with the perception that the procedure by which the decision is made was fair ${ }^{126.271}$. The best "technical" solution cannot be implemented if the process of decision making is perceived as unfair or biased.

The second response to this challenge is more fundamental. Our experiences from previous projects along with the implementation of our model indicate clearly that the public has something to contribute to the planning process. Experts and regulators are often restricted in their assessment of a project and confine their analysis to the typical risk factors. Local specifics or other dimensions of concerns are often neglected. Public participation helps to include these concerns in the decision making process and to avoid potential consequences of which the experts involved were not aware ${ }^{[21.28]}$.

Finally, participation is not only instrumental in resolving social conflicts and finding appropriate solutions to problems, it is also an expression of our political culture. Technocratic decision making is incompatible with democratic ideals ${ }^{[7]}$. The involvement of affected parties represents the political value of government by the people, not just for the people. If we take the ideal of democracy seriously, public participation is a normative prerequisite.

\section{Literature}

[1] P. M. Wiedemann, S. Femers: Conflict Analysis and Management: Public Participation in Waste Management Decision Making, Research Center Jülich (September 1990).

[2] J. Habermas: Communication and the Evolution of Society, Heinemann, London (1979).

[3] J. Habermas: Theory of Communicative Action, Volume l: Reason and the Rationalization of Society. Beacon Press, Boston (1983); Volume 2: System and Lifeworld, ibid. (1987).

[4] N. Crosby, J. M. Kelly, P. Schaefer: "Citizen Panels: A New Approach to Citizen Participation", Public Administration Review 46 (1986) 170-178.

[5] T. R. Burns, R. Ueberhorst: Creative Democracy: Systematic Conflict Resolution and Policymaking in a World of High Science and Technology, Praeger, New York (1988).

[6] K. Chen, J. C. Mathes: "Value-Oriented Social Decision Analysis: A Communication Tool for Public Decision Making on Technological Projects", in C. Vlek G. Cvetkovich (Ed.): Social Decision Methodology for Technological Projects, Kluwer, Dordrecht (1989), p. 111-132.

[7] D. J. Fiorino: "Citizen Participation and Environmental Risk: A Survey of Institutional Mechanisms", Science, Technology, and Human Values 15, 2 (Spring 1990) 226-243.

[8] G. J. Syme, E. Eaton: "Public Involvement as a Negotiation Process", Journal of Social Issues, 45 (1989) 87-107.

[9] O. Renn: "Risikokommunikation: Bedingungen und Probleme eines rationalen Diskurses über die Akzeptabilität von Risiken", in J. Schneider (Ed.): Risiko und Sicherheit technischer Systeme. Auf der Suche nach neuen Ansätzen, Birkhäuser, Basel (1991), p. 193-210.

[10] D. von Winterfeldt, W. Edwards: Decision Analysis and Behavioral Research, Cambridge University Press, Cambridge MA (1986)

[11] O. Renn, U. Kotte: "Umfassende Bewertung der vier Pfade der Enquete-Kommission auf der Basis eines Indikatorkatalogs", in G. Albrecht, H. U. Stegelmann (Ed.): Energie im Brennpunkt, HTV Edition "Technik und Sozialer Wandel", München (1984), p. 190-232.

[12] T. Webler, D. Levine, H. Rakel, O. Renn: "The Group Delphi: A Novel Attempt at
Reducing Uncertainty", Technological Forecasting and Social Change 4 (1991) 252-263.

[13] P. C. Dienel: Die Planungszelle, Westdeutscher Verlag, Opladen (1978); New Options for Paricipatory Democracy, Werkstattpapier No.1 of the University of Wuppertal (1980)

[14] R. L. Keeney, O. Renn, D. van Winterfeldt, U. Kotte: Die Wertbaumanalyse. Entscheidungshilfe für die Politik. HTV Edition "Technik und Sozialer Wandel", München (1984)

[15] R. L. Keeney, O. Renn, D. von Winterfeldt: "Structuring West Germany's Energy Objectives", Energy Policy 15, 4 (August 1987) 352-362.

[16] O. Renn: "Premises of Risk Communication: Results of Two Participatory Experiments", in R. E. Kasperson, P. J. Stallen (Ed.): Conmunicating Risks to the Public: International Perspectives, Kluwer Academic, Dordrecht (1991), p. 457-481.

[17] O. Renn, R. Goble, D. Levine, H. Rakel, T. Webler: Citizen Participation for Sludge Management, Final Report to the New Jersey Department of Environmental Protection (CENTED, Clark University), Worcester MA (1989)

[18] P. C. Dienel, D. Garbe: Zukünftige Energiepolitik. Ein Bürgergutachten, HTV Edition "Technik und Sozialer Wandel", München (1985)

[19] P. C. Dienel: Bürgergutachten: Regelung sozialer Folgen neuer Informations. technologien, IGEBP Verlag, Leverkusen (1986); Bürgergutachten: ISDN, Bergische Universität Wuppertal (1991)

[20] O. Renn, G. Albrecht, U. Kotte, H. P. Peters, H. U. Stegelmann: Sozialverträgliche Energiepolitik. Ein Gurachten fiur die Bundesregierung, HTV Edition "Technik und Sozialer Wandel", München (1985).

[21] D. J. Fiorino: "Technical and Democratic Values in Risk Analysis", Risk Analysis 9 (1989) 293-299

[22] L. Kathlene, J. A. Martin: "Enhancing Citizen Participation: Panel Designs, Perspectives, and Policy Formation", Policy Analysis and Management 10 (1991) 46-63.

[23] H. H. Bownes: "Should Trial by Jury be Eliminated in Complex Cases?" Risk- Issues in Health and Safety 1, 1 (Winter 1990) 73-78.

[24] State of New Jersey: Transcripts of Proceedings, Pemberton Township. Municipal Building (Division of Environmental Protection), Trenton (August 14, 1985).

[25] A. L. Page, T. J. Logan, J. A. Ryan: Land Application of Sewage Sludge, Lewis Publishers, Chelsea M] (1987)

[26] G. A. Almond, S. Verba: The Civic Culture: Political Attitudes and Democracy in Five Nations, Princeton University Press, Princeton (1963).

[27] S. Rayner, R. Cantor: "How Fair is Safe Enough? The Cultural Approach to Societal Teclinology Choice", Risk Analysis 7 (1987) 3-10.

[28] M. Kraft: "Evaluating Technology Through Public Participation: The Nuclear Waste Disposal Controversy", in M. E. Kradt, N. J. Vig (Ed): Technology and Politics, Duke University Press, Durham NC (1988), p. 253-277. 